\title{
Biochemical Marker of Bone Turnover (osteocalcin) and Its Relation with Salivary Secretion
}

\author{
Enas M. El-Bendary, Sahar A. El-Sawy and Maessa M. El-Nahas \\ Physiology Department, Faculty of Medicine, Tanta University
}

\begin{abstract}
The aim of the present study is to determine if saliva can be used as a marker of osteoporosis in overiectomized dogs and for the effect of hormone replacement therapy in this model. Eighteen female dogs were divided into three groups: Sham operated, ovariectomized (OVX) and ovariectomized treated with hormone replacement therapy (HRT). Unstimulated saliva was collected to measure flow rate $\mathrm{ml} / \mathrm{hour}$, outputs of $\alpha$-amylase, total protein, bicarbonate and calcium. Bone turnover was estimated by measuring serum and salivary osteocalcin. The results of the present work showed that ovariectomy (OVX) produces a significant decrease in salivary flow rate and outputs of salivary constituents studied with significant negative correlation with both salivary and serum osteocalcin. While ovariectomy with hormone replacement therapy decrease salivary and serum osteocalcin and causes a significant increase in flow of saliva and outputs of all salivary parameters that show significant negative correlation with both osteocalcins, however the flow rate and outputs of all salivary constituents, serum and salivary osteocalcin does not return to sham operated level. In Conclusion the flow rate and output of these salivary parameters are improved by HRT and that whole saliva is considered as a valuable tool for assessing human marker of bone turnover.
\end{abstract}

Key words: Salivary secretion, osteocalcin.

\section{INTRODUCTION}

Menopause is a physiological process occurring in the fifth decade of life in women due to irreversible decrease in the hormonal and reproductive functions of the ovaries, some women enter the menopause after surgical removal of both ovaries. ${ }^{(1)}$

Spontaneous or surgical menopause is usually associated with osteoporosis. $^{(2)}$

Osteoporosis is attributed to imbalance between bone formation and bone resorption followed by bone mass loss. Osteoporosis can be corrected by hormone replacement therapy. ${ }^{(3)}$

Osteocalcin is a non collagenous protein found in bones .Yasui etal postulated that osteocalcin is a marker of inhibition of bone formation and bone turnover. ${ }^{(4)}$ In overiectomized animals there is an increase in bone turnover and osteocalcin is up regulated suggesting that bone turnover was accelerated in these animals. $^{(2)}$

The incidence of dry mouth are common in menopausal females and is affected by sex steroid. ${ }^{(5)}$ Previous 
report on the effects of sex steroid on salivary secretion are few and most of them only studied the effect of these hormones on the flow rate. ${ }^{(6)}$

Saliva is a biological fluid, sample collection is invasive more convenient for the patient and health workers, it need no additional expertise or help particularly when the number sequential samples may be required. ${ }^{(7)}$

The aim of this work is to determine if saliva can be used as a marker of osteoporosis in overiectomized dogs and for the effect of hormone replacement therapy in this model.

\section{MATERIAL \& METHODS}

This study was carried out on eighteen female dogs weighing between $10-12 \mathrm{~kg}$, they were kept on normal diet. The animals were randomly divided into three groups. (6 dog each).

Group I: sham operated group

They underwent sham surgical procedure and subcutaneously injected with similar volume of solvent vehicle for four weeks.

\section{Group II ovariectomized OVX} group

They are subjected to bilateral ovariectomy through midline incision under general anesthesia with thiopentone sodium $15 \mathrm{mg} / \mathrm{kg}$ body weight and allowed to recover for 4 weeks and then treated with similar volume of the solvent vehicle for four weeks.

\section{Group III OVX + hormone replacement therapy HRT group}

They are subjected to ovariectomy as in group II and then received a daily subcutaneous injection of estrogen $30 \mu \mathrm{g} / \mathrm{kg}$ and progesterone $1 \mathrm{mg} / \mathrm{kg} \mathrm{BW}$. for four weeks. $^{(3)}$

At the end of experimental period, unstimulated parotid salivary secretion is collected for one hour from dogs of all groups studied using special device formed of two plastic cups which were placed over the orifices of the parotid duct and held in place by peripheral suction chamber.

The values of all salivary samples was measured. They were analyzed for $\alpha$ amylase by the method of Tietz ${ }^{(8)}$ total protein content using the method of Silvrman, ${ }^{(9)}$ Bicarbonate concentration using the procedure of (Gyory \& Edwards), ${ }^{(\mathbf{1 0})}$ and calcium concentration by the method of atomic absorption spectroscopy. Salivary osteocalcin was measured using the technique described by (Bullon et al.,) ${ }^{(11)}$ the outputs/hour of all these salivary parameters was calculated.

Also a blood sample was collected from all these dogs at the end of the experimental period to measure the level of serum osteocalcin. $^{(12)}$

\section{Statistical analysis}

Data were expressed as the mean + SD statistical difference involving multiple group comparisons were determined by one way ANOVA $(\mathrm{P}<0.05)$ differences between individual groups were determined with Scheffe (f) test $(\mathrm{P}<0.05)$, Pearson correlation coefficient using SPSS computer program version $11 .{ }^{(13)}$

\section{RESULTS}

It is evident from the results of the present work table (1) that in OVX dogs there is a significant 
reduction in the salivary flow rate, outputs of $\alpha$ amylase, total protein bicarbonate and calcium levels, however it produces a significant increase in both salivary and serum osteocalcin as compared to sham operated dogs $(\mathrm{p}<0.05)$.

On the other hand HRT when given to OVX dog causes significant elevation of all these parameters when these results are compared with those of OVX dogs. But HRT causes significant reduction in both salivary and serum osteocalcin as compared to OVX dogs $(\mathrm{p}<0.05)$.

However the flow rate and outputs of all salivary constituents, serum and salivary osteocalcin does not return to sham operated level.

Table (2) shows the correlations between the studied parameters in ovariectomized group. There is a significant negative correlation between salivary osteocalcin and flow rate and output values of $\alpha$-amylase, total protein, bicarbonate and calcium (r) values $\quad(-0.581,-0.616,-0.847,-$ $0.524,-0.687)$ respectively, also serum osteocalcin show significant negative correlation between them (r) values ($0.541,-0.607,-0.689, \quad-0.623,-0.512)$ respectively.

Correlations between the studied parameters in OVX+ HRT group, reveal significant negative correlation between salivary osteocalcin and flow rate and output values of $\alpha$-amylase, total protein, bicarbonate and calcium (r) values $\quad(-0.839-0.530,-0.520,-$ $0.863,-0.874$ respectively, Also serum osteocalcin show significant negative correlation between them $(\mathrm{r})$ values ($0.524,-0.739,-0.599, \quad-0.638,-0.731)$ respectively.

Table (1): Effect of OVX and with HRT on some salivary and serum parameters. (Mean values \pm S.D)

\begin{tabular}{|l|c|c|c|c|}
\hline \multicolumn{1}{|c|}{ parameters } & $\begin{array}{c}\text { Sham } \\
\text { operated(n=6) }\end{array}$ & $\begin{array}{c}\text { OVX } \\
(\mathbf{n = 6})\end{array}$ & $\begin{array}{c}\text { OVX+HRT } \\
(\mathbf{n = 6})\end{array}$ & F- test \\
\hline $\begin{array}{l}\text { Salivary flow rate } \\
\text { ml/hour }\end{array}$ & $37.68 \pm 6.29$ & $21.16 \pm 2.52$ & $27.06 \pm 4.60$ & $\mathbf{1 9 . 2 0 4 *}$ \\
\hline $\begin{array}{l}\text { Salivary } \boldsymbol{\alpha} \text { amylase } \\
\text { IU/hour }\end{array}$ & $18.69 \pm 8.98$ & $10.57 \pm 2.88$ & $14.38 \pm 5.46$ & $\mathbf{5 . 1 3 2 *}$ \\
\hline $\begin{array}{l}\text { Salivary total protein } \\
\text { mg/hour }\end{array}$ & $103.7 \pm 74.6$ & $79.10 \pm 15.82$ & $95.6 \pm 32.76$ & $\mathbf{4 . 9 6 3 *}$ \\
\hline $\begin{array}{l}\text { Salivary bicarbonate } \\
\text { mEq/hour }\end{array}$ & $2.57 \pm 0.93$ & $1.72 \pm 0.35$ & $1.91 \pm 0.49$ & $\mathbf{2 . 9 9 7 *}$ \\
\hline $\begin{array}{l}\text { Salivary calcium mEq } \\
\text { /hour }\end{array}$ & $0.196 \pm 0.037$ & $0.105 \pm 0.018$ & $0.138 \pm 0.031$ & $\mathbf{1 3 . 7 0 7 *}$ \\
\hline $\begin{array}{l}\text { Salivary osteocalcin } \\
\text { ng/hour }\end{array}$ & $67.43 \pm 9.81$ & $88.62 \pm 6.78$ & $75.77 \pm 6.09$ & $\mathbf{1 1 . 4 3 0 *}$ \\
\hline Serum ostoecalcin ng/ml & $76.55+5.32$ & $96.11 \pm 3.40$ & $80.9 \pm 5.48$ & $\mathbf{2 7 . 0 4 8 *}$ \\
\hline
\end{tabular}

OVX: ovariectomy HRT: Hormone replacement therapy

* Denotes significant $(p<0.05)$. 
Table (2) Correlations between salivary and serum osteocalcin with the studied parameters in ovariectomized \& hormonal replacement therapy groups

\begin{tabular}{|l|c|c|c|c|}
\hline \multirow{2}{*}{ parameters } & \multicolumn{2}{|c|}{ OVX } & \multicolumn{2}{c|}{ OVX+HRT } \\
\cline { 2 - 5 } & $\begin{array}{c}\text { Salivary } \\
\text { osteocalcin } \\
\mathbf{n g} / \mathbf{h} \\
\mathbf{r}\end{array}$ & $\begin{array}{c}\text { Serum } \\
\text { osteocalcin } \\
\mathbf{n g} / \mathbf{m l} \\
\mathbf{r}\end{array}$ & $\begin{array}{c}\text { Salivary } \\
\text { osteocalcin } \\
\mathbf{n g} / \mathbf{h} \\
\mathbf{r}\end{array}$ & $\begin{array}{c}\text { Serum } \\
\text { osteocalcin } \\
\mathbf{n g} / \mathbf{m l} \\
\mathbf{r}\end{array}$ \\
\hline Salivary flow rate $\mathbf{~ m l / h}$ & $-0.581^{*}$ & $-0.541^{*}$ & $-0.839^{*}$ & $-0.524^{*}$ \\
\hline Salivary $\boldsymbol{\alpha}$-amylase IU/h & $-0.616^{*}$ & $-0.607^{*}$ & $-0.530^{*}$ & $-0.739^{*}$ \\
\hline $\begin{array}{l}\text { Salivary } \\
\text { total protein } \mathbf{~ m g / h ~}\end{array}$ & $-0.847^{*}$ & $-0.689^{*}$ & $-0.520^{*}$ & $-0.599^{*}$ \\
\hline $\begin{array}{l}\text { Salivary bicarbonate } \\
\mathbf{m E q} / \mathbf{h}\end{array}$ & $-0.524^{*}$ & $-0.623^{*}$ & $-0.863^{*}$ & $-0.638^{*}$ \\
\hline Salivary calcium $\mathbf{m E q} / \mathbf{h}$ & $-0.687^{*}$ & $-0.512^{*}$ & $-0.874^{*}$ & $-0.731^{*}$ \\
\hline
\end{tabular}

OVX: ovariectomy HRT: Hormone replacement therapy

* Correlation is significant at the 0.05 level

\section{DISCUSSION}

It is evident from the present results that there is a significant lowering of parotid salivary flow rate, outputs of all parameters studied in ovariectomized dogs as compared to sham operated. But there is a significant increase in all these values in ovariectomized animals with hormone replacement therapy as compared to ovariectomy alone.

Few published reports on the effect of menopause or ovariectomy and hormone replacement therapy on salivary secretion ${ }^{(\mathbf{1 3})}$

The most significant oral sign found in menopause were the feeling of dry mouth which might be due to qualitative and quantitative changes in salivary secretion. ${ }^{(3)}$

Data on the effect of menopause (natural or surgical) on salivary flow rate are confusing increase, ${ }^{(14)}$ decrease $^{(15)}$ or no change. ${ }^{(16)}$
Parotid salivary flow rate and composition show hormonal related changes suggesting that estrogen play an important role in salivary gland physiology. ${ }^{(4)}$ Although many hormones are known to regulate salivary composition, the specific mechanism by which estrogen modulate salivary gland function is poorly understood, ${ }^{(17)}$ and the precise mechanism by which estrogen mediate these effect is unclear. ${ }^{(18)}$

Estrogen deprivation in ovariectomized dog or when given as replacement therapy, could affect salivary secretion directly and this effect may be mediated by estrogen receptor beta which in identified in both mucous and serous acinar and ductal cells of the parotid gland, (19) this distribution of sex hormone receptors might explain the effects of this hormone on salivary flow rate, organic and inorganic constituents. Secretion of protein and bicarbonate are sex hormone related. ${ }^{(20)}$ However no information about the effect of 
hormone replacement therapy on salivary electrolyte and on calcium in particular. (21)

A second factor that also affect salivary secretion is the blood supply to the gland because secretion always require adequate nutrients from the blood which is needed by the secreting cells. ${ }^{(22)}$

Estrogen has an essential role in mediating arterial vasodilatation increasing the blood flow, ${ }^{(23)}$ this is achieved by stimulating endothelial prostacyclin synthesis (a potent vasodilator) and by inhibiting the vasoconstrictor effect of endothelin. (24) Estrogen also mediates vascular reactivity via nitric oxide synthesis. ${ }^{(25)}$

It can be concluded that hormone replacement therapy causes qualitative and quantitative improvement of salivary secretion

Bilateral ovariectomy is considered in this work as an experimental model of osteoporosis .This model exhibit a progressive loss of bone matrix through process that is similar to what occur in postmenopausal osteoporosis secondary to estrogen deficiency. ${ }^{(2)}$

Estrogen deficiency leads to dramatic increase in the activation of new remodeling unit of the surface of the bone (high bone turnover) which undergo bone resorption, in addition the amount of bone formed within the individual remodeling unit is less than resorbed (negative remodeling balance). ${ }^{(26)}$

The state of high bone turnover in overiectomized group is partially corrected in this study by hormone replacement therapy; this suggestion was supported by the significant increase in serum and salivary osteocalcin in overictomized animals which is nearly reversed by hormone replacement therapy (table 1).

Osteocalcin measurement provide a valid non invasive specific marker for bone turnover. ${ }^{(27)}$

Table (2) reveal that there is a significant negative correlation between either serum osteocalcin or salivary osteocalcin and all salivary parameters studied in both the overictomized and overictomized with hormone replacement therapy groups . So, it can be concluded that whole saliva may be a valuable tool for assessing human marker of bone turnover

\section{REFERENCES}

1. Ganong WF (2005). Review of Medical physiology. Mc Craw Hill twenty second edition p 386.

2. Jordan KM, Cooper C (2002). Epidemiology of osteoporosis Best Pract Res Clin Rheumatol. 16(5):795-806.

3. Pines A, Strurdee DW, Bisk hauser MH, de Villiers T, Naftolin F, Compel A, farmer R, Barlow D (2008). HRT in the early menopause scientific evidence and common perceptions. Climacteric; 11(4): 267-272.

4. Yasui T, Uemura $H$, Tomita $J$, Umino Y (2006). Different effects of oral conjugated equine estrogen and transdermal estrogen on undercarboxylated osteocalcin concentration in post menopausal women.Menopause, 13(4)651659.

5. Gupta A, Epstein JB, Serous, H (2006). Hyposalivation in elderly 
patients $\mathrm{J}$ can. Dent association; 72: 841.

6. Bergdahl M (2000). Salivary flow rate and oral complaint in adult dental patients community dent oral Epidemiol; 28:59.

7. Kaufman E, Lamster B (2002). The diagnostic application of saliva. Crit. Rev oral Biol Med $13 ; 197$.

8. Tietz, NW (1982). Fundamentals of Clinical Chemistry. Philadelphia, W, B. Saunders Company, p.627.

9. Silvrman LM (1986).In textbook of clinical chemistry, N.W Tietz Ed W.B, Saunders Philadelphia, PP, 585.

10. Gyory, AZ and Edwards, KDG (1967). Simultaneous titrimetric determination of bicarbonate and titretable acids in urine Aust.J.exp.BIOL.med.Sci.45.141147.

11. Bullon $\mathbf{P , G o b e r n a ~} B, G$ Guerrero JM, Segura JJ, Perez-Cano R, Martinez-Sahuquillo $\mathbf{A}(\mathbf{2 0 0 5})$. Serum, saliva and gingival cervical fluid osteocalcin: their relation to periodontal status and bone mineral density in postmenopausal women. J Periodontol, 76:513-519.

12. Indrayan $A$ and Sarmukaddam SB (2001): Medical biostatics $1^{\text {st }}$ ed., Marcel Dekker Delhi, India.

13. Yalçin F, Gurgan S, Gurgan $T$ (2005). The effect of menopause, hormone replacement therapy (HRT), alendronate (ALN), and calcium supplements on saliva. J Contemp Dent Pract. 15; 6(2):1017.

14. Rohleder N, Wolf JM, Maldonado EF, Kirschbaum C
(2006). The psychosocial stressinduced increase in salivary alpha-amylase is independent of saliva flow rate. Psychophysiology.;43(6):645-52.

15. Bardow A, Nyvad $B$, Nauntofte B (2001). Relationships between medication intake, complaints of dry mouth, salivary flow rate and composition, and the rate of tooth demineralization in situ. Arch Oral Biol. May;46(5):413-23.

16. Ghezzi EM, Wagner-Lange LA, Schork MA, Metter EJ, Baum BJ, Streckfus CF, Ship JA (2000). Longitudinal influence of age, menopause, hormone replacement therapy, and other medications on parotid flow rates in healthy women. J Gerontol A Biol Sci Med Sci.; 55(1):M34-42.

17. Eliasson L, Carlén A, Laine $M$, Birkhed D (2003). Minor gland and whole saliva in postmenopausal women using a low potency oestrogen (oestriol). Arch Oral Biol.; 48(7):511-517.

18. Grodstein F, Clarkson TB, Manson JE. (2003). Understanding the divergent data on postmenopausal hormone therapy. N Engl J Med 13; 348 (7):645-650.

19. Välimaa $H$, Savolainen $S$, Soukka T, Silvoniemi $\mathbf{P}$, Mäkelä S, Kujari H, Gustafsson JA, Laine M (2004). Estrogen receptor-beta is the predominant estrogen receptor subtype in human oral epithelium and salivary glands. J Endocrinol. 180 (1):55-62.

20. Friedlander AH (2002). The physiology, medical management of oral implications of 
menopause. J Am Dent Associ; 130:173.

21. Sewón L, Laine M, Karjalainen S, Leimola-Virtanen $\mathbf{R}$, Hiidenkari $\mathbf{T}$, Helenius $\mathbf{H}$ (2000). The effect of hormone replacement therapy on salivary calcium concentrations in menopausal women. Arch Oral Biol.; 45(3):201-206.

22. Herrington DM, Espeland MA, Crouse JR 3rd, Robertson J, Riley WA, McBurnie MA, Burke GL (2001). Estrogen replacement and brachial artery flow-mediated vasodilation in older women. Arterioscler Thromb Vasc Biol.; 21(12):19551961.

23. Grodstein F, Manson JE, Colditz GA, Willett WC, Speizer FE, Stampfer MJ (2000). A prospective, observational study of postmenopausal hormone therapy and primary prevention of cardiovascular disease. Ann Intern Med 19; 133(12):933-41.

24. De Kleijn MJ, Wilmink HW, Bots ML, Bak AA, van der Schouw YT, Planellas J, Engelen S, Banga JD, Grobbee DE (2001). Hormone replacement therapy and endothelial function. Results of a randomized controlled trial in healthy postmenopausal women. Atherosclerosis.; 159(2):357-65.

25. Mendelooher ME (2000). Non genomic ER mediated activation of endothelial nitric oxide synthase how does it work what does it mear. Cir Res,; 87: 956.

26. Seibel MJ (2003). Biochemical markers of bone remodeling. Endocrinol Metab Clin North Am.; 32(1):83-113.

27. Seibel MJ (2003). Biochemical markers of bone metabolism in the assessment of osteoporosis: useful or not? J Endocrinol Invest.; 26(5):464-71. 


\section{العلامة الكيموحيوية للتحول العظمى (أوستيوكالسين) و علاقته بإفراز اللعاب}

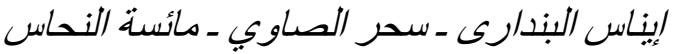

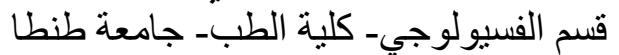

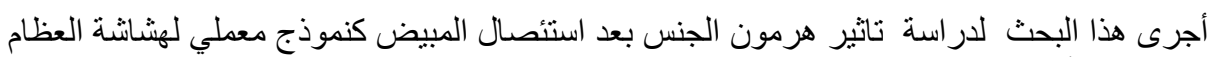

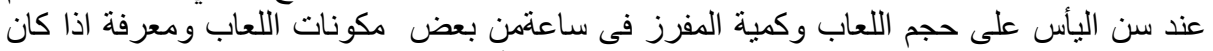

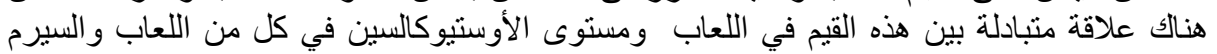

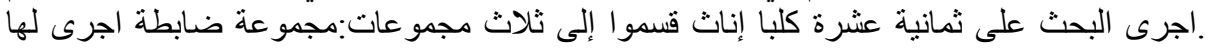

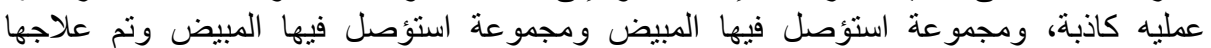

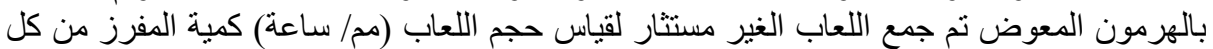

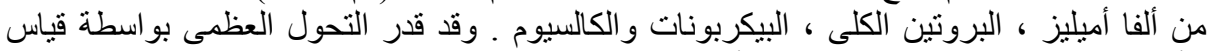

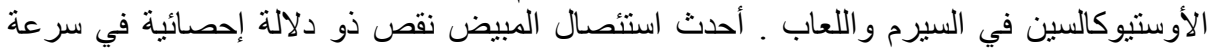

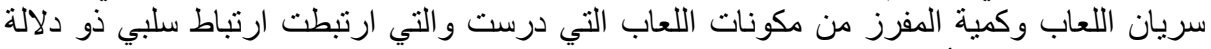

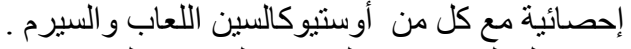

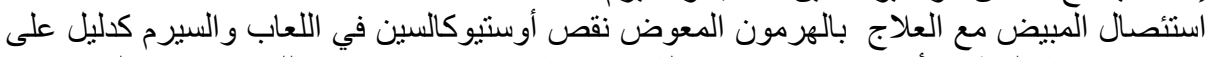

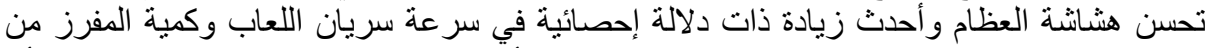

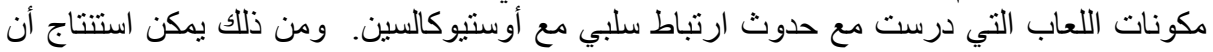

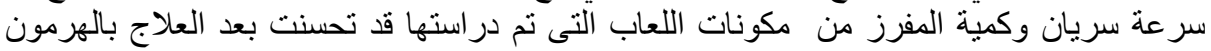

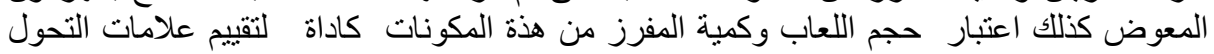

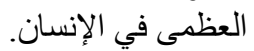

